\title{
Metagenomic Characterization of Planktonic Communities During a Mucilage Event in the Çanakkale Strait (Dardanelles), Turkey
}

\author{
Sevdan YILMAZ ${ }^{1 *} \quad$ Mehmet Ali KUCUKER $^{2} \quad$ Dilek KAHRAMAN YILMAZ $^{3}$ \\ ${ }^{1 *}$ Department of Aquaculture, Faculty of Marine Sciences and Technology, Canakkale Onsekiz Mart University, Canakkale, Turkey \\ ${ }^{2}$ İzmir Institute of Technology, Faculty of Engineering, Department of Environmental Engineering, Gülbahçe Campus, İzmir, Turkey \\ ${ }^{3}$ Department of Marine Biology, Faculty of Marine Sciences and Technology, Çnakkale Onsekiz Mart University, Çanakkale, Turkey
}

How to cite: Yılmaz, S., Kucuker, A.M. \& Yılmaz Kahraman, D. (2021). Metagenomic characterization of planktonic communities during a mucilage event in the Çanakkale Strait (Dardanelles), Turkey. J. Anatolian Env. and Anim. Sciences, 6(3), 421-427.

Atıf yapmak için: Yılmaz, S., Kucuker, A.M. \& Yılmaz Kahraman, D. (2021). Çanakkale Boğazı'nda (Dardanel) Müsilaj Oluşumu Sırasında Planktonik Toplulukların Metagenomik Karakterizasyonu, Türkiye. Anadolu Çev. ve Hay. Dergisi, 6(3), 421-427.

D : https://orcid.org/0000-0002-4809-5809

(iD : https://orcid.org/0000-0001-9648-8925

(iD) : https://orcid.org/0000-0002-9626-5446
*Corresponding author's:

Sevdan YILMAZ

Çanakkale Onsekiz Mart University

Faculty of Marine Sciences and Technology

Çanakkale, Turkey

凶: sevdanyilmaz@comu.edu.tr
Abstract: The present study investigates the planktonic communities through metagenomics sequencing during a mucilage event in the Çanakkale Strait (Dardanelles), Turkey. Mucilage samples were collected in May 2021 during an intense period of mucilage formation in three different stations of Dardanelles (Station 1: $40^{\circ} 9^{\prime} 8.09^{\prime \prime} \mathrm{N}, 26^{\circ} 24^{\prime} 16.19^{\prime \prime E}$; Station 2: $40^{\circ} 6^{\prime} 21.62^{\prime \prime} \mathrm{N}, 26^{\circ} 22^{\prime} 41.25^{\prime \prime E}$; Station 3: $40^{\circ} 6^{\prime} 42.78^{\prime \prime} \mathrm{N}$, $\left.26^{\circ} 23^{\prime} 57.00^{\prime \prime E}\right)$. The dominant planktonic eukaryotes, at the phylum level, were Dinoflagellata $(38.57 \%)$, Protalveolata (15.03\%), Diatomea (12.41\%), Nematozoa (8.44\%), Apicomplexa $(6.79 \%)$ and Chlorophyta $(5.43 \%)$, which constituted $86.68 \%$ of the total number of sequences. The most dominant OTUs $(>10 \%)$, were Alexandrium and Syndiniales Group II. other dominant OTUs (>2\%) were Viscosia sp., Lankesteria, Arcocellulus, Thalassiosira and Nannochloris. This study has clarified the situation of planktonic communities during a mucilage event in the Çanakkale Strait (Dardanelles), Turkey. As a result, the most dominant genus was Alexandrium, which has been known to produce mucilage. Some Alexandrium species can produce toxins, cause severe impacts on human health, and lead to bivalve, shrimp, and fish mortality. Therefore, a more detailed study is needed to determine the Alexandrium toxins in the mucilage structure. In addition, the heavy metal content of the obtained mucilage was investigated, and the concentrations of the As and $\mathrm{Cr}$ are above the disposal limits in the landfill sites. Therefore, collected mucilage from the sea surface should be checked before sending it to landfill sites in terms of the heavy metal content.

Keywords: Canakkale strait (dardanelles), eukaryotic biodiversity, heavy metal, metagenomic sequencing, mucilage.

\section{Çanakkale Boğazı'nda (Dardanel) Müsilaj Oluşumu Sırasında Planktonik Toplulukların Metagenomik Karakterizasyonu, Türkiye}

\section{*Sorumlu yazar:}

Sevdan YILMAZ

Çanakkale Onsekiz Mart Üniversitesi

Deniz Bilimleri ve Teknolojisi Fakültesi

Çanakkale, Türkiye

凶: sevdanyilmaz@comu.edu.tr
Öz: Bu çalışmada Çanakkale Boğazı'ında (Dardanel) müsilaj oluşumu sırasında planktonik toplulukların kompozisyonları metagenomik yaklaşımla araștırılmıștır. Müsilaj örnekleri, Çanakkale Boğazı'nın üç farklı

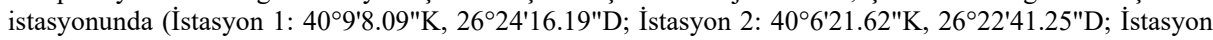
3: $\left.40^{\circ} 6^{\prime} 42.78^{\prime \prime} \mathrm{K}, 26^{\circ} 23^{\prime} 57.00^{\prime \prime D}\right)$ yoğun müsilaj oluşumu gözlemlenen Mayıs 2021'de toplanmıștır. Filum düzeyinde toplam sekans sayısının $86.68 \%$ ini kapsayan baskın planktonik ökaryotlar, Dinoflagellata $(\% 38,57)$, Protalveolata $(\% 15,03)$, Diatomea $(\% 12,41)$, Nematozoa $(\% 8,44)$, Apicomplexa $(\% 6,79)$ ve Chlorophyta $(\% 5,43)$ olarak belirlenmiștir. En baskın OTU'ler $(>\% 10)$, Alexandrium ve Syndiniales Group II olup, diğer baskın OTU'lar (>\%2) ise Viscosia sp., Lankesteria, Arcocellulus, Thalassiosira ve Nannochloris olmuştur. Bu çalışma, Türkiye'de meydana gelen bir müsilaj olayı sırasında Çanakkale Boğazı'nda planktonik toplulukların durumunu netleştirmiştir. Sonuç olarak, en baskın cinsin müsilaj üretme kabiliyeti olduğu bilinen Alexandrium olduğu belirlenmiştir. Bazı Alexandrium türleri toksin üretebilir, insan sağlığ üzerinde ciddi etkilere neden olabilir ve çift kabuklu, karides ve balık ölümlerine yol açabilir. Bu nedenle müsilaj yapısındaki Alexandrium toksinlerinin belirlenmesi için daha detaylı bir çalışmaya ihtiyaç vardır. Ayrıca elde edilen müsilajın ağır metal içeriği araştırılmıştır. Müsilajın yapısındaki As ve Cr konsantrasyonları atıklar için belirlenen düzenli depolama sahalarına bertaraf etme sınırlarının üzerindedir. $\mathrm{Bu}$ nedenle deniz yüzeyinden toplanan müsilajın düzenli depolama sahalarına gönderilmeden önce ağır metal içeriği kontrol edilmelidir.

Anahtar kelimeler: Ağır metal, çanakkale boğazı (canakkale), metagenomik dizileme, müsilaj, ökaryotik biyoçeșitlilik. 


\section{INTRODUCTION}

The Dardanelles (Çanakkale Strait), a strait that separates Asian and European continents and connects the Aegean Sea and Sea of Marmara, is a significant watercourse for the international vessels. There are two major currents in the strait. The first one is a surface current flowing from the Black Sea to the Sea of Marmara through the Bosphorus and the Agean Sea through the Dardanelles. The second one is the undercurrent which flows from the Agean Sea to the Black Sea (Artüz et al., 2007; Yücel \& Tarhan 2019). The pollution load of the Sea of Marmara increased incrementally, thus affecting the Dardanelles. The growth of population and industrialization on the seaside, insufficient treatment of domestic and industrial wastewater (Artüz et al., 2007; Okus et al., 2008), climate change, and global warming (Balkis et al., 2011) led to severe biologic problems in the marine environment. Consequently, intense mucilage has been found in Turkish seas in recent years for the first time. The mucilage problem, which was recorded in the Sea of Marmara (Aktan et al., 2008; Tüfekçi et al., 2010; Balkis et al., 2011) and the Dardanelles (Yentür et al., 2013) between 20072008 for the first time, reached a critical level to affect fishery, tourism, and social life in the first two quarters of 2021.

It has been reported that mucilage remarkably decreased the density of zooplankton groups, which are critical nutritional sources for larvae of marine species both in the Bosphorus (Okyar et al., 2015) and the Dardanelles (Yentür et al., 2013). Besides, research conducted between December 2020 and March 2021 reported the impacts of mucilage on endangered coral Cladocora caespitosa, which are essential for the Dardanelles and coral-rich habitats in Eceabat and Nara regions, which result in coral mortalities (Özalp, 2021).

It was reported that Chrysophaeum taylorii, which spreads through tropical and subtropical Atlantic and Western Pacific shores and produces mucilage in benthic areas, produced mucilage for the first time in the benthic area in the Aegean Sea in May 2011 (Aktan \& Topaloğlu 2011). In another study conducted on the shores of Büyükada Island (the Marmara Sea) in 2008, it was detected that Clindrotheca closterium, Pseudo-nitzschia sp., Skeletonema costatum, Thalassiosira rotula, and Gonyaulax fragilis species were the dominant species in the mucilage structure (Balkis et al., 2011). In June 2007, when mucilage structure is observed in the north-eastern Sea of Marmara, it was observed that Gonyaulax hyalina and Thalassiosira gravida species, which are known to cause mucilage, were dominant (Tas et al., 2020). Moreover, the research conducted in the Sea of Marmara and the Gulf of İzmit between October 2007 and February 2008 reported that Gonyaulax fragilis, Skeletonema costatum and Cylindrotheca closterium were the dominant species of the mucilage structure (Tüfekçi et al., 2010). Yet information on the diversity of planktonic communities in the mucilage structure from the Sea of Marmara ecosystem is limited only to microscopic descriptions.

This study researches metagenome analysis of the mucilage structure reaching a critical level in the Dardanelles in the first two quarters of 2021, distribution of planktonic communities, and heavy metal content of the mucilage.

\section{MATERIALS AND METHODS}

Samples and Heavy Metal Analysis: Sampling was performed as part of three nearly simultaneous expeditions to different regions of the Dardanelles (Station 1: $40^{\circ} 9^{\prime} 8.09^{\prime \prime} \mathrm{N}, 26^{\circ} 24^{\prime} 16.19^{\prime \prime} \mathrm{E}$; Station 2: $40^{\circ} 6{ }^{\prime} 21.62^{\prime \prime} \mathrm{N}$, $26^{\circ} 22^{\prime} 41.25^{\prime \prime E}$; Station 3: 406'42.78"N, 26²3'57.00"E) in May 2021. Sampling points in the Dardanelles is shown in Figure 1. Samples were collected using a 5L Niskin bottle at the maximum depth of $2 \mathrm{~m}$ according to the ISO 5667-9 method for the analyses by means of the Turkish Coast Guard ship in Çanakkale (ISO 5667-9, 1992). The mucilage samples were concentrated after centrifuging (Hettich, Rotofix 32A, Germany) at $6000 \mathrm{rpm}$ for $10 \mathrm{~min}$ and then filtered through a pre-weighed glass fiber filter (Merck Millipore, AP40, Germany). The filter was heated to constant mass at $70 \pm 1^{\circ} \mathrm{C}$ for $24 \mathrm{~h}$ and then weighed to determine the dry solid. The filters and a blank filter with $9 \mathrm{ml} \mathrm{HNO}_{3}$ and $1 \mathrm{ml}$ of $\mathrm{H}_{2} \mathrm{O}_{2}$ were digested in pressurized digestion vessels using a microwave oven (CEM, MARS6, USA). The temperature was ramped to $210^{\circ} \mathrm{C}$ within 15 minutes and held for 20 minutes at a constant microwave digestion temperature. Digested samples were diluted after cooling and centrifuging for soluble metal analysis. Soluble heavy metals in the diluted samples were analyzed by an inductively coupled plasma-optical emission spectrometry (ICP-OES / Agilent 5110 Dual View, USA).

DNA Extraction, PCR Amplification and Bioinformatics Analysis: Total DNA was extracted from the mucilage samples using GeneMATRIX Kit (EURx Poland) according to the manufacturer's instructions. The eukaryote nuclear 18S rRNA gene was amplified by PCR, using the eukaryotic-specific primers $18 \mathrm{~S}-566 \mathrm{~F}$ CAGCAGCCGCGGTAATTCC and 18S-1200R CCCGTGTTGAGTCAAATTAAGC (Hadziavdic et al., 2014). 


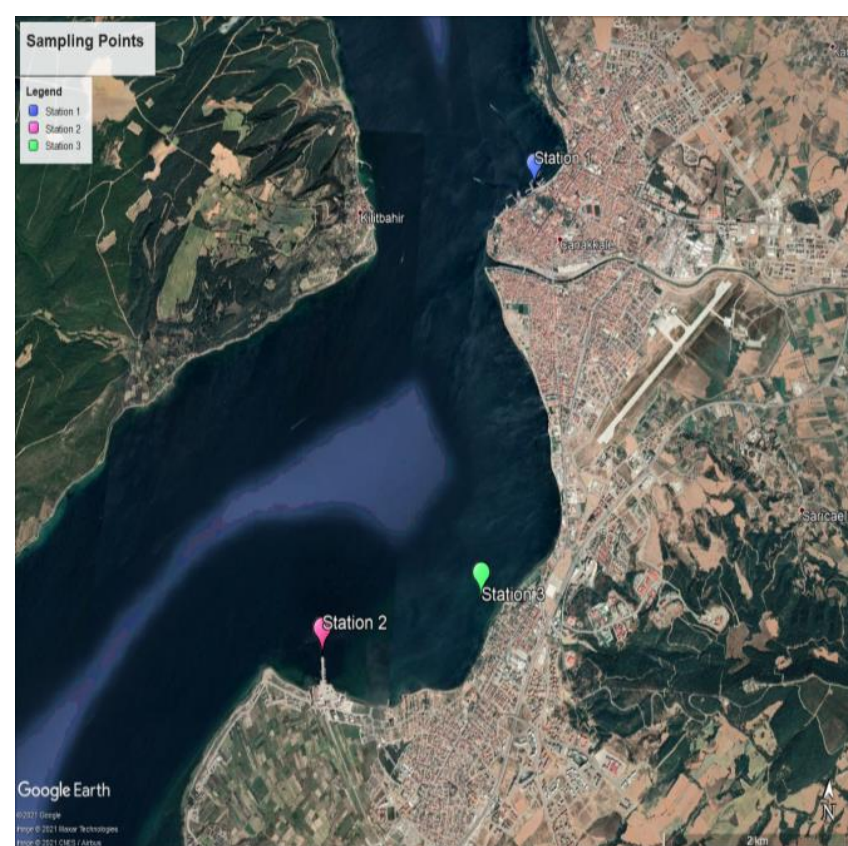

Figure 1. Sampling points in the Dardanelles (Google Earth Map).

The first PCR amplification was performed in $25 \mu \mathrm{L}$ volume, containing $10 \mu \mathrm{L}$ of $2 \mathrm{X}$ KAPA HotStart ReadyMix (Roche, Switzerland), $5 \mu \mathrm{L}$ of each primer (1 $\mu \mathrm{M})$, and $2.5 \mu \mathrm{L}$ of template DNA. Thermal cycling conditions were: $95^{\circ} \mathrm{C}$ for 3 min followed by 25 cycles of $95^{\circ} \mathrm{C}$ for the $30 \mathrm{~s}, 55^{\circ} \mathrm{C}$ for $30 \mathrm{~s}, 72^{\circ} \mathrm{C}$ for $30 \mathrm{~s}$, and a 5 min extension at $72{ }^{\circ} \mathrm{C}$ and a final hold at $4{ }^{\circ} \mathrm{C}$. The second PCR amplification was performed in $50 \mu \mathrm{L}$ volume, and reactions contained $25 \mu \mathrm{L}$ of KAPA HiFi HotStart ReadyMix, $5 \mu \mathrm{L}$ Nextera XT1 (N7xx), $5 \mu \mathrm{L}$ Nextera XT2 (S5xx), $5 \mu \mathrm{L}$ of cleaned PCR product and $10 \mu \mathrm{l}$ PCR Grade water. The second thermocycling conditions were: $95^{\circ} \mathrm{C}$ for $3 \mathrm{~min}$ followed by 8 cycles of $95^{\circ} \mathrm{C}$ for $30 \mathrm{~s}, 55^{\circ} \mathrm{C}$ for $30 \mathrm{~s}, 72^{\circ} \mathrm{C}$ for $30 \mathrm{~s}$, and a $5 \mathrm{~min}$ extension at $72^{\circ} \mathrm{C}$ and a final hold at $4^{\circ} \mathrm{C}$. The sequencing $(2 \times 250 \mathrm{bp})$ was performed on the MiSeq platform. The processing and quality control was conducted using DADA2 (Callahan et al., 2016). Chimera check was conducted with DADA2. Amplicons with a quality score of more than 20 were retained, and amplicons were filtered and trimmed with DADA2. Taxonomic classification was performed against the SILVA 138 ribosomal RNA gene database (Quast et al., 2012).

\section{RESULTS AND DISCUSSION}

Planktonic community compositions: The dominant planktonic eukaryotes, at the phylum level, were Dinoflagellata (38.57\%), Protalveolata (15.03\%), Diatomea (12.41\%), Nematozoa (8.44\%), Apicomplexa $(6.79 \%)$ and Chlorophyta $(5.43 \%)$, which constituted $86.68 \%$ of the total number of sequences (Figure 2).

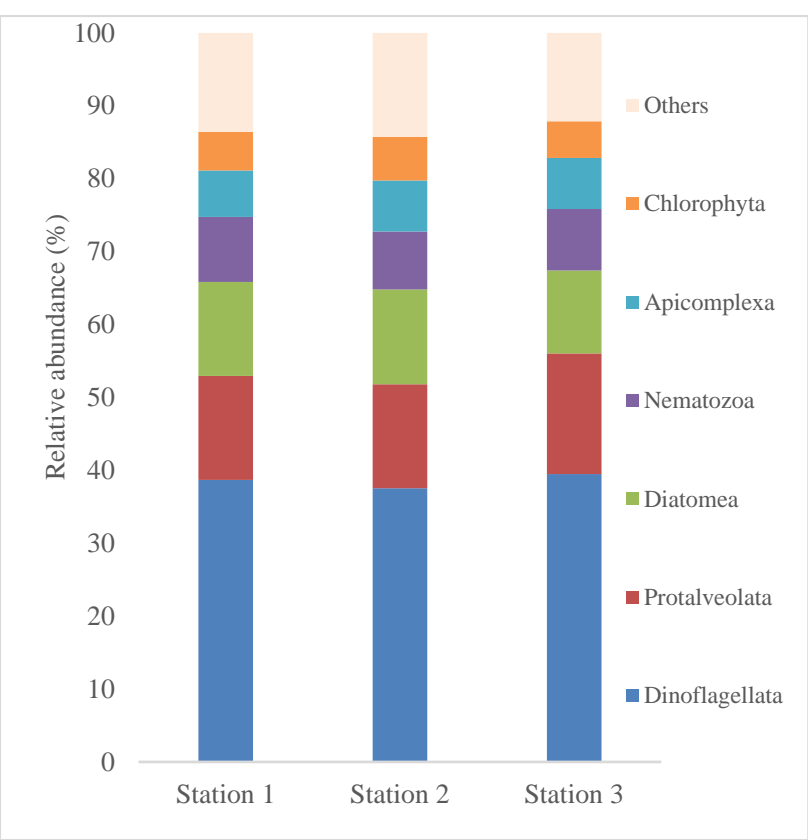

Figure 2. Planktonic community compositions during the mucilage event.

The most dominant OTUs (>10\%) (Table 1) were Alexandrium with 25442 reads (35.36\%), Syndiniales_Group_II with 7958 reads (11.06\%). Other dominant OTUs (>2\%) (Table 1) were Viscosia sp with 6305 reads $(8.76 \%)$, Lankesteria with 4217 reads $(5.86 \%)$, Arcocellulus with 3719 reads (5.17), Thalassiosira with 2133 (2.96) and Nannochloris with 1753 reads (2.44\%).

Table 1. Top seven of planktonic eukaryotes. Results are given at species level or a higher taxonomic level if the sequences could not be assigned to a species.

\begin{tabular}{lc}
\hline & Dominant OTUs (\%) \\
\hline Alexandrium (Dinophyceae) & 35.36 \\
Syndiniales_Group_II (Protalveolata) & 11.06 \\
Viscosia sp (Enoplea) & 8.76 \\
Lankesteria (Apicomplexa) & 5.86 \\
Arcocellulus (Diatomea) & 5.17 \\
Thalassiosira (Diatomea) & 2.96 \\
Nannochloris (Chlorophyta) & 2.44 \\
\hline
\end{tabular}

A plethora of studies has been conducted on planktonic communities in water sources with metagenomic approaches. In the present study conducted in May 2021, when intense mucilage was observed, the dominant group was found to be the Alexandrium genus. Among many dinoflagellate species, the Alexandrium genus, in particular, produces toxins resulting in problems on human and environmental health as well as tourism economies (Vingiani et al., 2020). It was reported that Alexandrium species have the capability to produce mucilage and lead to shrimp and fish mortality in regions with algae bloom (Landsberg et al., 2002; Lewis et al., 2018). Alexandrium minutum is the most common toxic species in the western Mediterranean Sea (Vila et al., 2001). It caused larval mortality of some bivalve species and reduced valve gape and clearance rate of large-sized 
class bivalves (May et al., 2010). The presence of Alexandrium species in the water column and sediment in the Gulf of Gemlik (the Sea of Marmara) between 20112012 was reported (Balkis et al., 2016; Balkis \& Taş 2016). A. minutum cysts were determined in the sediments of Izmir Bay (Aydın et al., 2011; Aydın \& Uzar, 2013). Moreover, vegetative forms of $A$. minutum were reported from the Marmara Sea (Balkis, 2004; Tüfekçi et al., 2010).

This study reports the second most dominant group as Syndiniales Group_II: endosymbionts of tintinnid ciliates, crustaceans, fish, protozoa, algae, and other dinoflagellates in particular (Luo et al., 2016). All the Syndiniales species identified have been reported to kill their hosts, including other protists and metazoans, and then release dinospores (Coats \& Park., 2002; Guillou et al., 2008; Clarke et al., 2019). For this reason, Syndiniales species can potentially affect plankton population dynamics and biogeochemical cycling. The research in the literature has demonstrated that parasitic Syndiniales species assume the role of biological control agent on dinoflagellates that increase by algae bloom (Chambouvet et al., 2008; Mazzillo et al., 2011). As proof of this finding and parallel to the present study, $27.70 \%$ dinoflagellata and $12.81 \%$ parasitic Syndiniales Group I were dominant groups in polluted waters (Thessaloniki Bay, Greece) (Tsipas, 2020).

In this study, free-living marine nematode Viscosia sp. was detected in mucilage structure. In a similar vein, it was found among dominant nematode species in the Ligurian Sea, North-West Mediterranean (Moreno et al., 2009), Strait of Sicily, Central Mediterranean Sea (Sandulli et al., 2015), Aegean Sea, Eastern Mediterranean (Lampadariou \& Eleftheriou, 2018) and the Black Sea (Ürkmez et al., 2016).

Gregarines, a large group of Apicomplexans, live in the body cavities of invertebrates, and some species attach to the epithelial tissues of the host, invading the intestinal lumen. In contrast, others invade the reproductive systems (Leander et al., 2016). As a member of this group, Lankesteria was found present in the mucilage structure at a rate of $5.86 \%$. Lankesteria species were isolated in ascidians on the Central California Coast (Levine et al., 1981), and they were reported to cause large-scale infection in the ascidian Ciona intestinalis species (Mita et al., 2012). No report of Lankesteria species has been found in the literature for the Sea of Marmara and the Aegean Sea. However, the closest information to the present study area is Lankesteria metandrocarpae species in Varna Bay (the Black Sea) (Dzhembekova et al., 2017).

In this study, two Diatomea genus Arcocellulus and Thalassiosira, were detected in mucilage structure. Similarly, they were dominant groups during algae bloom periods in the Mediterranean Sea (Percopo et al., 2011).
Thalassiosira species were reported among the most abundant diatom species forming resting stages (Montresor et al., 2013). Parallel to the present study, Tsipas (2020) reported that Thalassiosira was found among the dominant groups in polluted Thessaloniki Bay (Greece) at a rate of $2.41 \%$.

It has been reported that the green algae Nannochloris genus belonging to the chlorellaceae family, identified among the dominant groups in the mucilage structure in the present study, contains species that lead to ecosystem disruptive algae blooms (Zhang et al., 2015; Mercado et al., 2021). Dzhembekova et al. (2017) detected the presence of Nannochloris $s p$. in Varna Bay (the Black Sea), though not intense, in their research on harmful algae. However, there has been no report of an algae bloom caused by Nannochloris species in Turkish waters in the literature.

This study determines planktonic communities in the mucilage structure, which started to be observed in Turkey's water column, surface, and bottom at the beginning of 2021 and reached severe levels as of May. The finding is that the Alexandrium genus, a dinoflagellate, and the Syndiniales Group_II, which is known to act as a biological control agent on the species belonging to this genus, are among the dominant groups is particularly significant. Alexandrium species have been known the capability to produce mucilage. Some Alexandrium species can cause severe impacts on human health and lead to bivalve, shrimp and fish mortality. Therefore, a more detailed study is needed to determine the Alexandrium toxins in the mucilage structure.

The heavy metal content of the mucilage: There is limited information on the heavy metal concentration of mucilage in the literature. Therefore, the heavy metal content of the obtained mucilage from the Dardanelles was defined in this study. On the other hand, the collected mucilage from the surface of the Marmara Sea was sent to the landfill site for disposal. Thus, the concentration of the heavy metals in the obtained mucilage is crucial for environmental concerns. The microorganisms in the mucilage, such as microalgae and bacteria, have negative functional groups on their surface. These groups are more like to bind positive ions (i.e. heavy metals) in the sea. Due to this reason, the accumulation of heavy metals in the mucilage can occur. The heavy metal concentration of the mucilage and limitations for landfilling are given in the Table 2. The limit concentrations of heavy metals in nonhazardous waste in the Regulation on Landfilling of Wastes by the Republic of Turkey Ministry of Environment and Urbanization are 2, 100, 1, 10, 50, 0.2, $10,10,10,0.5$ and $50 \mathrm{mg} / \mathrm{kg}$ dry solid for As, Ba, Cd, Cr, $\mathrm{Cu}, \mathrm{Hg}, \mathrm{Mo}, \mathrm{Ni}, \mathrm{Pb}, \mathrm{Se}$ and $\mathrm{Zn}$, respectively (TMEU, 2019). 
Table 2. The heavy metal concentration $(\mathrm{mg} / \mathrm{kg})$ of the mucilage and limitations for landfilling

\begin{tabular}{|c|c|c|c|c|c|c|c|c|c|c|c|}
\hline Stations & As & $\mathbf{B a}$ & Cd & $\mathrm{Cr}$ & $\mathrm{Cu}$ & $\mathbf{H g}$ & Mo & $\mathbf{N i}$ & $\mathbf{P b}$ & $\mathbf{B a}$ & $\mathbf{Z n}$ \\
\hline Station 1 & 3.10 & 0.03 & 0.18 & 10.80 & 13.12 & 0.14 & 5.59 & 7.67 & 2.37 & ND & 0.77 \\
\hline Station 2 & 4.45 & ND & 0.12 & 21.77 & 1.08 & 0.18 & 7.96 & 7.22 & 2.06 & ND & ND \\
\hline Station 3 & $\mathrm{ND}^{*}$ & ND & ND & 6.72 & 6.09 & ND & 4.73 & 3.71 & ND & ND & ND \\
\hline
\end{tabular}

The third sampling point (Station 3) is very close to the residential area. The water movement is very limited in that area as well; thus, the heavy metal content of the Station 3 could be lower than the other stations. According to the results, the total concentrations of all heavy metals in the mucilage complied with the regulation, except for As and $\mathrm{Cr}$. Therefore, the collected mucilage from the sea surface should be checked before sending it to landfill sites in terms of the heavy metal content.

\section{ACKNOWLEDGEMENTS}

The authors like to thank the Turkish Coast Guard Command in Çanakkale for their helpful collaboration in sampling. Environmental Research Center at İzmir Institute of Technology is gratefully acknowledged for heavy metal analyses.

\section{REFERENCES}

Aktan, Y. \& Topaloğlu, B. (2011). First record of Chrysophaeum taylorii Lewis \& Bryan and their benthic mucilaginous aggregates in the Aegean Sea (Eastern Mediterranean). Journal of the Black Sea / Mediterranean Environment, 17(2), 159170.

Aktan, Y., Dede, A. \& Çiftci, P.S. (2008). Mucilage event associated with diatoms and dinoflagellates in Sea of Marmara, Turkey. Harmful Algae News, 36, 13.

Artüz, M.L., Okay, I.A., Mater, B., Artüz, O.B., Gürseler, G. \& Okay, N. (2007). Bilimsel Açıdan Marmara Denizi. İstanbul: Union of Turkish Bar Associations publication.

Aydın, H. \& Uzar, S. (2013). Some potentially toxic dinoflagellate cysts in recent sediments from İzmir Bay. Su Ürünleri Dergisi, 30(3), 109-114. DOI: 10.12714/egejfas.2013.30.3.04

Aydın, H., Matsuoka, K. \& Minareci, E. (2011). Distribution of dinoflagellate cysts in recent sediments from Izmir Bay (Aegean Sea, Eastern Mediterranean). Marine Micropaleontology, 80(1-2), 44-52. DOI: 10.1016/j.marmicro.2011.03.004

Balkis, N. (2004). List of phytoplankton of Sea of Marmara. Journal of the Black Sea / Mediterranean Environment, 10, 123-141.
Balkis, N. \& Taş, S. (2016). Phytoplankton of the Sea of Marmara: A review. In: Yücel, M., Özkan, K., \& Tezcan, D. (Eds.,). The sea of Marmara marine biodiversity fisheries conservation and governance. 1st ed., 326-343p, Turkish marine research foundation (TUDAV) Publication, Turkey.

Balkis, N., Atabay, H., Türetgen, I., Albayrak, S., Balkis, H. \& Tüfekçi, V. (2011). Role of singlecelled organisms in mucilage formation on the shores of Buyukada Island (the Marmara Sea). Marine Biological Association of the United Kingdom. Journal of the Marine Biological Association of the United Kingdom, 91(4), 771. DOI: 10.1017/S0025315410000081

Balkis, N., Balci, M., Giannakourou, A., Venetsanopoulou, A. \& Mudie, P. (2016). Dinoflagellate resting cysts in recent marine sediments from the Gulf of Gemlik (Marmara Sea, Turkey) and seasonal harmful algal blooms. Phycologia, 55(2), 187-209. DOI: 10.2216/1593.1

Callahan, B.J., McMurdie, P.J., Rosen, M.J., Han, A.W., Johnson, A.J.A. \& Holmes, S.P. (2016). DADA2: high-resolution sample inference from Illumina amplicon data. Nature Methods, 13(7), 581-583.

Chambouvet, A., Morin, P., Marie, D. \& Guillou, L. (2008). Control of toxic marine dinoflagellate blooms by serial parasitic killers. Science, 322(5905), 1254-1257. DOI: 10.1126/science. 1164387

Clarke, L.J., Bestley, S., Bissett, A. \& Deagle, B.E. (2019). A globally distributed Syndiniales parasite dominates the Southern Ocean microeukaryote community near the sea-ice edge. The ISME journal, 13(3), 734-737. DOI: 10.6084/m9.figshare.7151510.v1

Coats, D.W. \& Park, M.G. (2002). Parasitism of photosynthetic dinoflagellates by three strains of Amoebophrya (Dinophyta): Parasite survival, infectivity, generation time, and host specificity. Journal of Phycology, 38(3), 520-528. DOI: 10.1046/j.1529-8817.2002.01200.x

Dzhembekova, N., Urusizaki, S., Moncheva, S., Ivanova, P. \& Nagai, S. (2017). Applicability of massively parallel sequencing on monitoring 
harmful algae at Varna Bay in the Black Sea. Harmful Algae, $\mathbf{6 8}, \quad 40-51 . \quad$ DOI: 10.1016/j.hal.2017.07.004

Guillou, L., Viprey, M., Chambouvet, A., Welsh, R.M., Kirkham, A.R., Massana, R., Scanlan, D.J. \& Worden, A.Z. (2008). Widespread occurrence and genetic diversity of marine parasitoids belonging to Syndiniales (Alveolata). Environmental Microbiology, 10(12), 3349-3365. DOI: 10.1111/j.1462-2920.2008.01731.x

Hadziavdic, K., Lekang, K., Lanzen, A., Jonassen, I., Thompson, E.M. \& Troedsson, C. (2014). Characterization of the $18 \mathrm{~S}$ rRNA gene for designing universal eukaryote specific primers. Plos One, 9(2), e87624. DOI: 10.1371/journal.pone.0087624

Hallegraeff, G.M., Bolch, C., Blackburn, S.I. \& Oshima, Y. (1991). Species of the toxigenic dinoflagellate genus Alexandrium in southeastern Australian waters. Botanica Marina, 34, 575-587. DOI: 10.1515/botm.1991.34.6.575

ISO 5667-9. (1992). International Standards Organization (ISO), Water quality Sampling Part 9: Guidance on sampling from marine waters, Geneva, Switzerland.

Keleş, G., Yılmaz, S. \& Zengin, M. (2020). Possible economic effects of musilage on Sea of Marmara fisheries. International Journal of Agriculture Forestry and Life Sciences, 4(2), 173-177.

Lampadariou, N. \& Eleftheriou, A. (2018). Seasonal dynamics of meiofauna from the oligotrophic continental shelf of Crete (Aegean Sea, eastern Mediterranean). Journal of Experimental Marine Biology and Ecology, 502, 91-104. DOI: 10.1016/j.jembe.2017.12.014

Landsberg, J.H. (2002). The effects of harmful algal blooms on aquatic organisms. Reviews in Fisheries Science, 10(2), 113-390. DOI: 10.1080/20026491051695

Leander, B.S., Lloyd, S.A., Marshall, W. \& Landers, S.C. (2006). Phylogeny of marine gregarines (Apicomplexa)-Pterospora, Lithocystis and Lankesteria-and the origin (s) of coelomic parasitism. Protist, 157(1), 45-60. DOI: 10.1016/j.protis.2005.10.002

Levine, N.D. (1981). New Species of Lankesteria (Apicomplexa, Eugregarinida) from Ascidians on the Central California Coast. The Journal of Protozoology, 28(3), 363-370.

Lewis, A. M., Coates, L.N., Turner, A.D., Percy, L. \& Lewis, J. (2018). A review of the global distribution of Alexandrium minutum (Dinophyceae) and comments on ecology and associated paralytic shellfish toxin profiles, with a focus on Northern Europe. Journal of Phycology, 54(5), 581-598. DOI: 10.1111/jpy.12768

Luo, W., Li, H., Gao, S., Yu, Y., Lin, L. \& Zeng, Y. (2016). Molecular diversity of microbial eukaryotes in sea water from Fildes Peninsula, King George Island, Antarctica. Polar Biology, 39(4), 605-616. DOI: 10.1007/s00300-015-18158

May, S.P., Burkholder, J.M., Shumway, S.E., Hégaret, H., Wikfors, G.H. \& Frank, D. (2010). Effects of the toxic dinoflagellate Alexandrium monilatum on survival, grazing and behavioral response of three ecologically important bivalve molluscs. Harmful Algae, 9(3), 281-293. DOI: 10.1016/j.hal.2009.11.005

Mazzillo, F.F., Ryan, J.P. \& Silver, M.W. (2011). Parasitism as a biological control agent of dinoflagellate blooms in the California Current System. Harmful Algae, 10(6), 763-773. DOI: 10.1016/j.hal.2011.06.009

Mercado, J.M., Cortés, D., Gómez-Jakobsen, F., García-Gómez, C., Ouaissa, S., Yebra, L., ... \& Ruíz, J.M. (2021). Role of small-sized phytoplankton in triggering an ecosystem disruptive algal bloom in a Mediterranean hypersaline coastal lagoon. Marine Pollution Bulletin, 164, $111989 . \quad$ DOI: 10.1016/j.marpolbul.2021.111989

Mita, K., Kawai, N., Rueckert, S. \& Sasakura, Y. (2012). Large-scale infection of the ascidian Ciona intestinalis by the gregarine Lankesteria ascidiae in an inland culture system. Diseases of Aquatic Organisms, 101(3), 185-195. DOI: 10.3354/dao02534

Montresor, M., Di Prisco, C., Sarno, D., Margiotta, F. \& Zingone, A. (2013). Diversity and germination patterns of diatom resting stages at a coastal Mediterranean site. Marine Ecology Progress Series, 484, 79-95. DOI: 10.3354/meps 10236

Moreno, M., Albertelli, G. \& Fabiano, M. (2009). Nematode response to metal, PAHs and organic enrichment in tourist marinas of the Mediterranean Sea. Marine Pollution Bulletin, 58(8), 1192-1201. DOI: 10.1016/j.marpolbul.2009.03.016

Okus, E., Ozturk, I., Sur, H.I., Yuksek, A., Tas, S., Aslan-Yilmaz, A., ... \& Aydin, A.F. (2008). Critical evaluation of wastewater treatment and disposal strategies for Istanbul with regards to water quality monitoring study results. Desalination, 226(1-3), 231-248. DOI: 10.1016/j.desal.2007.02.109 
Okyar, M.İ., Üstün, F. \& Orun, D.A. (2015). Changes in abundance and community structure of the zooplankton population during the 2008 mucilage event in the northeastern Marmara Sea. Turkish Journal of Zoology, 39(1), 28-38. DOI: 10.3906/zoo-1308-11

Özalp, H.B. 2021. First massive mucilage event observed in deep waters of Çanakkale Strait (Dardanelles), Turkey. Journal of the Black Sea / Mediterranean Environment, 27, 49-66.

Percopo, I., Siano, R., Cerino, F., Sarno, D. \& Zingone, A. (2011). Phytoplankton diversity during the spring bloom in the northwestern Mediterranean Sea. Botanica Marina, 54, 243-267, DOI: 10.1515/BOT.2011.033

Quast, C., Pruesse, E., Yilmaz, P., Gerken, J., Schweer, T., Yarza, P., ... \& Glöckner, F.O. (2012). The SILVA ribosomal RNA gene database project: improved data processing and web-based tools. Nucleic Acids Research, 41, 590-596. DOI: 10.1093/nar/gks1219

Sandulli, R., Miljutin, D., Angeletti, L. \& Taviani, M. (2015). Meiobenthos and nematode assemblages from different deep-sea habitats of the Strait of Sicily (Central Mediterranean Sea). Mediterranean Marine Science, 16(2), 402-412. DOI: $10.12681 / \mathrm{mms} .1145$

Tas, S., Kus, D., \& Yilmaz, I.N. (2020). Temporal variations in phytoplankton composition in the northeastern Sea of Marmara: potentially toxic species and mucilage event. Mediterranean Marine Science, 21(3), 668-683. DOI: 10.12681/mms.22562

TMEU (2019). the Republic of Turkey Ministry of Environment and Urbanization, Regulation on Landfilling of Wastes, 30990th Official Gazette, Ankara.

Tsipas, G. (2020). Metagenomic characterization of unicellular eukaryotes in the urban Thessaloniki Bay. A thesis submitted for the degree of Master of Science (MSc) in Bioeconomy Law, Regulation and Management. 63 p.

Tüfekçi, V., Balkis, N., Beken, Ç.P., Ediger, D. \& Mantikci, M. (2010). Phytoplankton composition and environmental conditions of the mucilage event in the Sea of Marmara. Turkish Journal of Biology, 34(2), 199-210. DOI: 10.3906/biy-08121

Ürkmez, D., Sezgin, M., Karaçuha, M.E. \& Öksüz, İ. (2016). Meiobenthic Assemblages from the Southwestern Coast of the Black Sea, İğneada (Turkey). Biologia, 71(9), 1017-1026. DOI: 10.1515/biolog-2016-0129
Vila, M., Camp, J., Garcés, E., Masó, M. \& Delgado, M. (2001). High resolution spatio-temporal detection of potentially harmful dinoflagellates in confined waters of the NW Mediterranean. Journal of Plankton Research, 23(5), 497-514. _ DOI: 10.1093/plankt/23.5.497

Vingiani, G.M., Štālberga, D., De Luca, P., Ianora, A., De Luca, D. \& Lauritano, C. (2020). De novo transcriptome of the non-saxitoxin producing Alexandrium tamutum reveals new insights on harmful dinoflagellates. Marine Drugs, 18(8), 386. DOI: $10.3390 / \mathrm{md} 18080386$

Yentur, R.E., Büyükateş, Y., Özen, Ö. \& Altın, A. (2013). The environmental and socio-economical effects of a biologic problem: Mucilage. Marine Science and Technology Bulletin, 2(2), 13-15.

Yücel, M., \& Tarhan, İ. (2019). Çanakkale Boğazı akıntı türbin modellenmesi. Uludă̆ Üniversitesi Mühendislik Fakültesi Dergisi, 24(3), 59-74. DOI: 10.17482/uumfd.412657

Zhang, X., Kan, J., Wang, J., Gu, H., Hu, J., Zhao, Y. \& Sun, J. (2015). First record of a large-scale bloom-causing species Nannochloropsis granulata (Monodopsidaceae, Eustigmatophyceae) in China Sea waters. Ecotoxicology, 24(7), 1430-1441. DOI: $10.1007 / \mathrm{s} 10646-015-1466-0$ 